\title{
РОЗРОБКА ПІДХОДІВ ЩОДО ВИКОРИСТАННЯ ПОБІЧНИХ ЕФЕКТІВ, ЯКІ ВИНИКАЮТЬ ВНАСЛІДОК ОПРОМІНЕННЯ РЕЗОНАНСНИМ НВЧ-СИГНАЛОМ ПОКРИТТІВ ЛІТАЛЬНИХ AIAPATIB
}

Анотація: за допомогою запропонованої в статті підходу можуть бути дослідженні перспективні способи отримання інформації про сучасні літальні апарати. Радіолокаційна інформація, яка необхідна для використання у автоматичних системах супроводження літаків, отримується шляхом резонансного збудження покриття фюзеляжу.

Ключові слова: ентальпія, радіопоглинаюче покриття, радіолокаційна інформація, резонанс, сигнал.

\section{Вступ}

Сучасна наука і техніка все більше приділяе уваги використанню енергетичних процесів, які викликають створення НВЧ електромагнітних полів, у практиці. Однак, широке застосування радіосигналів супроводжуеться спостереженням нових явищ та ефектів, природа яких не завжди розкрита. Інколи ці явища вважаються шкідливими і компенсуються відповідними заходами і засобами.

Проблемою є створення умов щодо дистанційної тимчасової зміни провідних властивостей для використання викликаних ефектів у існуючих способах радіолокації. Тенденція розвитку сучасних літальних засобів полягає у використанні неметалічних композитних матеріалів у конструкції планеру. Цей напрямок суттево знижуе можливості існуючих радіолокаційних засобів по виявленню та супроводженню таких літальних апаратів.

Зростання льотно-технічних характеристик сучасних авіаційних засобів вимагає підвищення ефективності радіотехнічних засобів, що удосконалюються або проектуються. Тому цілком природним е поглиблення теоретичного та експериментального дослідження процесу опромінення НВЧ-сигналами різної структури і частотного діапазону покриттів аеродинамічних літальних апаратів. Це пов'язано із сучасним перспективним напрямком розвитку авіації- використання різноманітних радіопоглинаючих матеріалів у покритті.

Метою статті $е$ аналіз явищ, що виникають в ході опромінення НВЧсигналами радіопоглинаючих матеріалів і розробка підходів щодо їх практичного застосування.

Попередні результати експериментальних досліджень [1] присвячені вивченню явища збудження внутрішньої кристалічної структури радіопоглинаючих матеріалів під час їх опромінення НВЧ-сигналом на

(c) I.P. Пархомей, 2012 
резонансній частоті і відкривають широкий простір для подальшого i більш глибокого вивчення зазначеного явища.

\section{Основна частина}

Донедавна вважалося, що такі явища як збудження радіопоглиначів, пробій ізоляторів, утворення стоячих хвиль в імпедансних покриттях носять супутній шкідливий характер і тому цілеспрямовано не відтворювалися в лабораторних умовах і не досліджувалися з точки зору технічної реалізації.

Низка проведених експериментів та їх метрологічна експертиза фрахівцями [1] дає можливість сформулювати гіпотезу, основними положеннями якої $е$ те, що у разі опромінення радіопоглинаючого матеріалу імпульсним НВЧ електромагнітним сигналом з несучою частотою, кратною частоті власних коливань атома кристалічної структури піддослідної речовини, то за умови збігу відповідних коливань фаз власних коливань атому (або базового елементу для молекулярних структур) і початкової фази сигналу опромінення можливо отримати енергетичний відгук, потужність якого в 4-16 разів перевищуе потужність, що витрачаеться для збудження. Дана гіпотеза грунтуеться на теоретичних положеннях Луї Дебройля, теореми Фабрі-Перо і умовах виникнення багатотональних сигналів [2].

Випадкові явища, що супроводжують процес опромінення радіопоглинаючих матеріалів можуть носити цілком керований характер, і головне, мати достатню обгрунтованість для технічної реалізації.

Із основних уявлень сучасної радіофрізики відомо, що будь-які матеріали здатні акумулювати НВЧ-енергію - так зване явище ентальпії [2], що супроводжуеться виділенням теплоти. Ефективна ентальпія різна для кожного матеріалу різна (табл. 1), але супроводжуеться загальними закономірностями: сублімацією і переходом речовини під час розігріву з твердої фази в газоподібну; оплавленням покриття з подальшим випарюванням рідинної фази; піролізом, що супроводжуеться термічним розпадом покриття без доступу повітря; хімічною взаємодією продуктів розпаду покриття з компонентами покриття (іонізація прикордонного шару покриття); механічною ерозією, пов'язаною з механічним виходом елементарних частинок з кристалічної структури (віднесення покриття) [3].

В таблиці 1 звертає на себе увагу вміст вуглецю в більшому чи меншому ступені практично у всіх радіопоглиначах та ізоляторах. По-перше, відповідно до закону Бугера-Ламбера, високий коефіцієнт поглинання енергії електромагнітного поля і доволі висока температура плавлення робить цю речовину дуже практичною при синтезі покриттів в технологіях штучного зниження площі віддзеркалення [5]. По-друге. можливо припустити, що відсутність вуглецю в матеріалі останньої позиції табл. 1 пояснюеться використанням ситалів у якості радіопрозорих обтічників. Тобто , наявність вуглецю у внутрішній структурі речовини 
Значення ефективної ентальпії $H_{e \phi}$ та температури $T$, що їі супроводжуе, для деяких радіопоглинаючих та ізоляційних

матеріалів*

\begin{tabular}{|l|c|c|l|l|l|}
\hline$№$ & Матеріал & Неф, Вт/кг & $\mathrm{T},{ }^{\circ} \mathrm{C}$ & $\begin{array}{l}\text { Вміст } \\
\text { вуглецю, } \%\end{array}$ & $\begin{array}{l}\text { Коефіціент розсіюва- } \\
\text { ння радіохвиль }\end{array}$ \\
\hline 1. & Графіт & 573,16 & 3447 & 100 & 0,01 \\
\hline 2. & Силікат & 181,93 & 3227 & 50 & 0,02 \\
\hline 3. & Сажа & 178,71 & 2227 & 33 & 0,031 \\
\hline 4. & AF & 161 & 2127 & $25-27$ & 0,06 \\
\hline 5. & LHX & 121,3 & 2100 & 18 & 0,1 \\
\hline 6. & TAS & 67,4 & 2027 & 15 & 0,1 \\
\hline 7. & Сітал & 40,4 & 2000 & 0 & 0,15 \\
\hline \multicolumn{5}{|c|}{ *Таблиця ск ладена за } \\
\hline
\end{tabular}

буде екранувати роботу радіолокаційних систем, що прикриваються обтічниками.

Широке використання різних композитних речовин в техніці НВЧ добре себе зарекомендували в ході їх експлуатації, але було помічено, що ресурс їх невеликий, а під час інтенсивного використання в циркуляторах та еквівалентах антен складає десятки годин і менше [6]. В роботах, опублікованих у виданнях МВТУ ім. Баумана, пов'язують це з дією вищезгаданого явища ентальпії. Таким чином, виникає зацікавленість до аналітичних залежностей, якими пов'язуеться ефективна ентальпія 3 іншими параметрами і характеристиками:

$$
H_{\mathrm{eq}}=\frac{\left(h_{1}-h_{0}\right)+\Gamma\left(h_{2}+\psi(E)\right)}{1+\frac{h_{3}}{E} \cdot \frac{q_{1}}{q_{2}}},
$$

де $h_{0}$ - початкова ентальпія речовини:

$h 1$ - ентальпія конденсованої фази речовини за умови температурного пошкодження речовини;

$h 2$ - тепловий ефект газифрікації компонентів речовини покриття під час НВЧ розігріву;

$\Gamma$ - ступінь газифрікації матеріалу покриття;

$h 3$ - тепловий ефект під час хімічного розпаду речовини покриття;

$\psi$ - коефіціент розігріву покриття за рахунок опромінення сигналами НВЧ енергї;

$q 1 / q 2$ - відношення питомих теплових потоків до опромінення і під час опромінення НВЧ-сигналом.

Якщо зважити на складові аналітичної залежності (1), то можна стверджувати, що розігрів покриття під час ентальпії прямо залежить від щільності потоку енергії електромагнітного НВЧ поля на одиницю маси та площі речовини. Як зазначалося, ентальпія є супутнє шкідливе явище радіоопромінення і широко спостерігалося, але не відтворювалося в лабораторних умовах. 
Якщо навчитися керувати даним явищем, то виникає обгрунтована можливість використання ентальпії в якості фактору радіолокації.

Така локація буде ефективним при виконання наступних умов:

- створення достатньої потужності на одиницю маси та площі на імпедансному покритті літального апарату;

- температура, що супроводжує ентальпію покриття повинна перевищувати температуру механічної ерозії фюзеляжу і несучих поверхонь літального апарату;

- фрактори локації повинні бути достатніми для виявлення літального апарату на фроні радіоперешкод.

Попередні розрахунки за допомогою відомих методик радіолокації та електродинаміки [7] (табл. 2) свідчать про те, що наземні радіолокаційні пристрої майже не можуть створити зазначених умов виникнення ентальпії, оскільки обмежені у можливостях елементної бази для створювання даних умов на великих дальностях (більше 100 км).

Таблиця 2

Зведена таблиця результатів моделювання умов виникнення ентальпії радіопоглинаючих покриттів.

\begin{tabular}{|c|c|c|c|c|c|}
\hline № & Пристрій & $\begin{array}{l}\text { Потужність, } \\
\text { МВт }\end{array}$ & $\begin{array}{l}\text { Дальність, } \\
\text { км }\end{array}$ & $\begin{array}{l}\text { Ентальпія, } \\
\text { Вт/кг }\end{array}$ & $\begin{array}{l}\text { Температура, } \\
{ }^{\circ}\end{array}$ \\
\hline 1. & наземна РЛС & 0,94 & 100 & 17 & 100 \\
\hline 2. & РЛС & 0,5 & 0,1 & 53 & 153 \\
\hline 3. & РЛС & 0,7 & 0,1 & 98 & 207 \\
\hline 4. & РЛС & $\begin{array}{l}0,5 \text { (за умови } \\
\text { резонансу) }\end{array}$ & 0,1 & 184 & 850 \\
\hline
\end{tabular}

Інші дві умови, що перераховувалися, залежать від властивостей матеріалів, з яких виготовлені сучасні літальні апарати (табл. 3):

Таблиця 3

Допустимі температури для матеріалів планерів літальних апаратів.

\begin{tabular}{|c|l|c|}
\hline № & Матеріал & $\begin{array}{l}\text { Гранично допустима } \\
\text { температура, }{ }^{\circ} \mathrm{C}\end{array}$ \\
\hline 1. & Магнієві сплави & $200-250$ \\
\hline 2. & Алюмінієво-магнієві сплави, дюралюмін & $250-300$ \\
\hline 3. & Титанові сплави & $400-600$ \\
\hline 4. & Сплави на основі нікелю, боридні сплави & $600-750$ \\
\hline
\end{tabular}

*Таблиця складена на основі даних з [7].

\section{Висновки}

Таким чином, якщо РЛС створить умови ентальпії покриття можливо допустити, що виникне розігрів не тільки покриття, а і елементів 
планера. Цей процес буде супроводжуватись сублімацією, хімічним розпадом і віднесенням речовини, що означає виникнення достатньо потужного теплового сигналу інфрачервоного діапазону хвиль.

Враховуючи результати моделювання, можливо припустити: електромагнітна локація може бути достатньо ефективною або за умови великої потужності, що означає принципові зміни конструкції РЛС, або за рахунок реалізації частотно-фразових резонансних методів локації.

\section{Література}

1. Солонніков В.Г., Рукосуєв В.В. Узагальнення результатів експериментальних досліджень щодо визначення фазових умов резонансного збудження радіопоглинаючих діелектриків. - К.: Зб. наук. пр. ННДЦ ОТ. - №1(30), 2006 р. - С.130 -136.

2. Баскаков С.И. Радиотехнические цепи и сигналы. - М.: Высшая школа, 1983. - 536c.

3. Ван-Драйст. Проблемы аэродинамического нагрева // Вопросы техники. - 1987. - №5. - С. 23 - 30.

4. Копытов М.И. РЛС. - М.: Машиностроение, 1970. - 366с.

5. Ванечев А.П. Приближенный метод расчета задачи теплопроводности // Труды МАП. - 1987. - №25. - С. 111 - 120.

6. Авдуевский В.С. Основы теплопередачи в авиационной технике. М.: Госиздат, 1980. - 286c.

7. Болховишинов В.Ф. Конструкция и эфрфективность летательных аппаратов // Труды ВВИА им. Жуковского. - 1992. - №5.

Отримано 15.05.2012 p. 